\title{
Evidence for Peroxynitrite and Cognates in Whole Smoke*
}

\author{
by Florian R. Perini and Edward A. Robinson \\ A. W. Spears Research Center, Lorillard Tobacco Co., Greensboro, N.C., USA.
}

\section{SUMMARY}

The peroxynitrite anion $\left(\mathrm{ONOO}^{-}\right)$, a major product of the gas-phase interaction between the superoxide radical and nitric oxide, has been detected by ion chromatography (IC) for the first time. IC analyses of cigarette whole mainstream smoke collected in deionized water (DiW), using a Dionex 4500i IC, a Dionex AS11 column, an aqueous sodium hydroxide linear gradient with conductivity suppression from 1-20 $m M \mathrm{NaOH}$, and conductivity coupled with diode array detection, revealed an unknown singly charged anion I incompletely resolved from nitrite. Gradient modification produced baseline resolution of $\mathbf{I}$ from nitrite and from a number of additional, previously undetected anions associated with smoke samples. Possible candidates for the unexpected smoke sample anion, including bromide, cyanide, and hydrogen hyponitrite were rejected for possible correspondence with the new smoke species on the basis of concentration range and chemical behavior. Chemical, chromatographic, and spectroscopic evidence supported the assignment of this smoke component as $\mathrm{ONOO}^{-}$. Mineral acid immediately destroyed $\mathbf{I}$ in the collected aqueous smoke medium. Both the retention time and the ultraviolet spectrum (UV) maximum at 302 $\mathrm{nm}$ for I were identical to those for synthetic peroxynitrite. The smoke from full flavor [28.5-30.4 mg total particulate matter (TPM)] filter cigarettes contained $2.4-3.3 \mu \mathrm{g} / \mathrm{cig}$ of this species. Levels were 4 to 5 times higher, up to 13 $\mu \mathrm{g} / \mathrm{cig}$, in cigarettes with the filters removed. [Beitr. Tabakforsch. Int. 21 (2005) 264-272]

\section{ZUSAMMENFASSUNG}

Das Peroxynitritanion $\left(\mathrm{ONOO}^{-}\right)$, das in der Gasphase durch die Interaktion zwischen dem Superoxidradikal und Stickstoffoxid als Hauptprodukt entsteht, wurde durch Ionenchromatographie (IC) erstmalig nachgewiesen. Die IC-Analyse des Gesamtrauchs von Zigaretten wurde in entionisiertem Wasser (DiW) mit einem Ionenchromatograph Dionex 4500i, einer Dionex AS11 Säule, einem linearen wässrigen Natriumhydroxid-Gradienten mit einer Unterdrückung der Leitfähigkeit von 1-20 $m M \mathrm{NaOH}$ und einer Leitfähigkeits-Diodenarray-Detektion durchgeführt. Diese Analyse wies auf das Vorliegen eines unbekannten, einfach geladenen Anions I hin, das vom Nitrit unvollständig getrennt war. Die Gradientenmodifikation führte zu einer annähernden Basislinien-Trennung der Substanz I vom Nitrit und einer Anzahl zusätzlicher, bisher in Rauchproben noch nicht nachgewiesener Anionen. Mögliche Kandidaten für das unerwartete Anion im Rauch wie Bromid, Cyanid und Wasserstoff Hyponitrit kamen wegen ihres mengenmäßigen Vorkommens und ihrer chemischen Eigenschaften als potentielle, neue Rauchkomponenten nicht in Frage. Chemische, chromatographische und spektroskopische Ergebnisse wiesen darauf hin, dass es sich bei dieser Rauchkomponente um $\mathrm{ONOO}^{-}$handelt. Durch Mineralsäure wurde I im gesammelten wässrigen Rauchmedium unvermittelt zerstört. Sowohl die Retentionszeit als auch das Maximum im UV-Spektrum bei $302 \mathrm{~nm}$ der Substanz I stimmten mit den Werten des synthetischen Peroxynitrits überein. Der Rauch von „Full-Flavour” [28,5-30,4 mg Gesamtpartikelmasse (TPM)] Filterzigaretten enthielt 2,4-3,4 $\mu \mathrm{g}$ pro Zigarette dieser Substanz. Diese Konzentrationen waren bei Zigaretten mit entferntem Filter vier bis fünf mal höher und erreichten Werte von bis zu $13 \mu \mathrm{g}$ pro Zigarette. [Beitr. Tabakforsch. Int. 21 (2005) 264-272]

\section{RESUME}

L'anion du peroxyde de nitrite $\left(\mathrm{ONOO}^{-}\right)$, composé majeur issu de l'interaction chimique dans la phase gazeuse du radical du super oxyde avec l'oxyde nitrique, a été détecté par chromatographie ionique (IC) pour la première fois. L'analyse IC de la fumée principale totale recueillie dans de l'eau désionisée (DiW), à l'aide d'un chromatographe IC Dixonex 4500i, une colonne AS11, un gradient linéaire d'hydroxyde de sodium aqueux avec suppression de la conductivité de 1-20 $m M \mathrm{NaOH}$, et la détection de conductivité couplée à un système à diodes, a révélé l'existence d'un anion I inconnu de charge unique, incomplètement résolu 
du nitrite. La modification du gradient conduit à une résolution approchée à la ligne de référence de $\mathbf{I}$ du nitrite et de plusieurs anions supplémentaires, précédemment pas détectés dans des échantillons de fumée. Les candidats potentiels de l'anion inattendu dans l'échantillon de fumée, comme le bromure, le cyanure et l'hyponitrite d'hydrogène, ne sont pas considérés comme concordants avec le nouveau composant de fumée à cause de leur gamme de concentrations et leurs propriétés chimiques. Des évidences chimiques, chromatographiques et spectroscopiques supportent l'inclusion de ce composé de fumée dans le groupe $\mathrm{ONOO}^{-}$. L'acide minérale a immédiatement détruit I présent dans le médium aqueux de fumée recueillie. Le temps de rétention et l'adsorption maximale du spectre ultraviolet (UV) à $302 \mathrm{~nm}$ du composé I sont identiques aux valeurs du peroxyde de nitrite synthétique. La fumée des cigarettes filtres plein arôme [28,5-30,4 mg de matière particulaire totale (TPM)] contiennent 2,4-3,3 $\mu \mathrm{g}$ de ce composé. Les valeurs sont de 4 à 5 fois plus élevées, jusqu'à $13 \mu \mathrm{g} /$ cigarette pour les cigarettes sans filtres. [Beitr. Tabakforsch. Int. 21 (2005) 264-272]

\section{INTRODUCTION}

Over the course of more than a dozen years, this Research Group has applied ion chromatography (IC) to the collection of anion profiles of whole smoke from both commercial and experimental cigarettes. Such profiles or ionograms are helpful in that they indicate the contribution of major anionic species to the smoke. Comparative data can then be used in modifying the smoke of certain cigarettes. Charged or ionic species are estimated to make up about $50 \%$ of the dry weight of a tobacco blend $(1,2)$. These entities include anions, cations, and transition metal ions. Among the major anions in water-collected whole smoke are nitrite, nitrate, chloride, and small carboxylates, such as acetate and formate. In several of our studies, whole smoke anion profiles have been gathered for comparative purposes. This type of collection and ion analysis was first presented at the $45^{\text {th }}$ Tobacco Chemists' Research Conference in 1991 (3). The aggregate value for the smoke nitrite and nitrate collected in water yields a ppm concentration, which is correlated with the concentration obtained for nitric oxide by chemiluminescence. The combined nitrite/nitrate is typically lower than the nitric oxide level. This effect might be related to incomplete dissolution of the nitric oxide in the water or the possibility that some of the nitrite produced reacts with available active compounds, such as phenols and related compounds (4,5).

Recently, during one of several routine ion analyses, an experimental cigarette designated as A with a total particulate matter (TPM) level of $2.5 \mathrm{mg} /$ cigarette generated an ionogram containing an unusual pattern in the nitrite/nitrate region. Specifically, an unexpected peak following the nitrite peak was partially separated from this important aqueous medium-collected species. This new ion is referred to as I. In order to determine the significance of this finding, it is necessary to examine the literature background for the generation of species related to the nitric oxide produced in whole tobacco smoke, and the possible influence of the collecting aqueous medium.
It is known that products of the reaction between superoxide and nitric oxide formed in smoke include peroxynitrite. There are numerous publications on this matter, with most of the focus on its cytotoxicity and mutagenicity. The common thread is the adverse effect or toxicity of peroxynitrite and related species, such as peroxyacetyl nitrate, as it relates to concurrently present chemicals in smoke or oxidative stress in smokers (6-25). One must point out that many of the publications involving peroxynitrite do not report direct analytical evidence of its presence in mixtures, but rather, indirect information based on the production of a multi-stage protein derivative, 3-nitrotyrosine, as a marker for peroxynitrite formation $(8-12,19)$. Furthermore, peroxyacetyl nitrate, a common gaseous photochemical compound in polluted air, when interacted with tyrosine, also produces 3-nitrotyrosine. Consequently, the benefit to the scientific community of directly measuring such a potentially elusive species as peroxynitrite by a reliable analytical means such as IC and conductivity/ultraviolet (UV) absorption detection, would be considerable. This mode of detection and quantification requires minimal sample treatment and thus affords speed and convenience. This would be particularly beneficial for studies involving the dynamic behavior of collected smoke. The scope of this paper is to establish instrumental and chemical evidence for the identification of the unexpected ion species I adjacent to the dominant whole smoke nitrite ion. Thus, two major thrusts were needed to achieve this end. One, a baseline resolution of the ionic species observed in the nitrite/nitrate region was imperative. Two, chromatographic peak correspondence with a known suspected entity, spectroscopically-based structural information, as well as chemical behavior were deemed necessary. The results of our investigation are thus expressed in the following exposition, presented, in part, at the $55^{\text {th }}$ Tobacco Science Research Conference in 2001 (26).

\section{EXPERIMENTAL}

\section{Reagents}

All aqueous media, including water for reagent dissolution and for the collection of smoke, were ultrafiltered (Supelco Part No. 5-8060, $0.2 \mu \mathrm{m}$ Nylon 66 membrane) deionized water (DiW) obtained from a Millipore Milli-Q PLUS unit. All standards for IC were prepared from ACS Reagent grade sodium salts of the appropriate anion (Fluka).

\section{Synthesis of peroxynitrite}

Due to the ion chromatographic behavior [the nitrite neighborhood at a retention time (r.t.), $20 \mathrm{~min}$ ] and chemical intuition, the suspected $\mathrm{ONOO}^{-}$was synthesized from isoamyl nitrite and hydrogen peroxide in alkali. This synthesis was based on UPPU and PRYOR's procedure (27). Hydrogen peroxide (30\%) was diluted with DiW to $7 \%$, then chilled to $4{ }^{\circ} \mathrm{C}$ and then added to $5 \mathrm{~N} \mathrm{NaOH}$ and $0.04 M$ diethylenetriaminepentaacetic acid (DTPA) in $0.05 \mathrm{~N} \mathrm{NaOH}$. The DPTA was included as a metal chelator to eliminate possible decomposition paths involving divalent cation impurities. Buffered peroxide was added to 


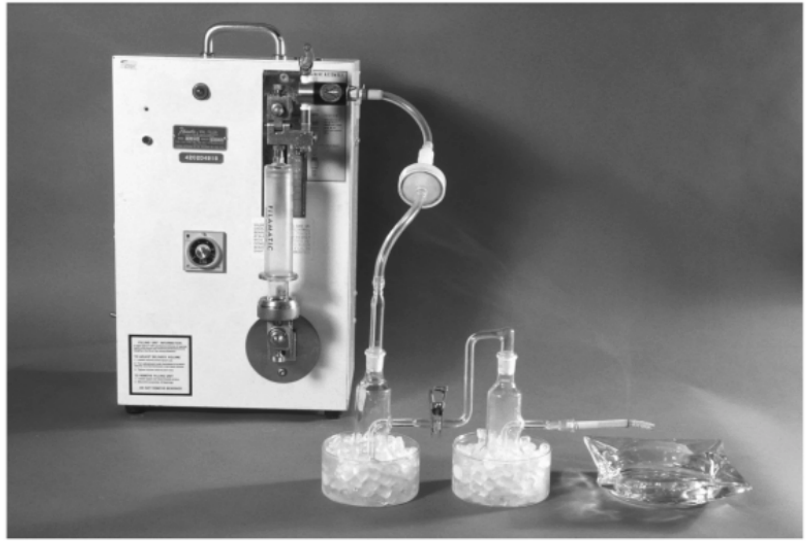

Figure 1. Apparatus used during whole smoke collection

Table 1. Program for anion separation on the lonPac $\AA$ AS 11 column

\begin{tabular}{l|c|c|c|c}
\hline $\begin{array}{l}\text { Time } \\
\text { (min) }\end{array}$ & $\begin{array}{c}100 \mathrm{mM} \\
\mathrm{NaOH}\end{array}$ & DiW & $\begin{array}{c}10 \mathrm{mM} \\
\mathrm{NaOH}\end{array}$ & Action \\
\hline 0 & 0 & 90 & 10 & Equilibrate \\
8.9 & 0 & 90 & 10 & Equilibrate \\
9.0 & 0 & 90 & 10 & Inject \\
9.2 & 0 & 90 & 10 & Load reset \\
40.0 & 10 & 90 & 0 & Gradient 1 \\
40.1 & 10 & 90 & 0 & Peak resolve \\
75.0 & 20 & 80 & 0 & Gradient 2 \\
75.1 & 0 & 90 & 10 & Reset \\
\hline
\end{tabular}

isoamyl nitrite with stirring. After 17 hours, the resulting mixture was extracted with $n$-hexane to remove unreacted isoamyl nitrite and isoamyl alcohol formed in the reaction. The product was split to give an untreated one (immediately stored in a freezer at $-15^{\circ} \mathrm{C}$ ) and one filtered through $\mathrm{MnO}_{2}$ to remove excess peroxide. The adsorption maximum at $302 \mathrm{~nm}\left(\varepsilon=1670 \mathrm{M}^{-1} \mathrm{~cm}^{-1}\right.$ in $\left.\mathrm{NaOH}, \mathrm{pH}, 11\right)$ strongly indicated the presence of peroxynitrite by correspondence with the UV data reported by UPPU (27). This reference material had a bulk concentration of $0.39 \mathrm{M}$. This sample was used for subsequent chromatographic operations.

\section{Cigarettes}

Cigarette A is an experimental cigarette with a TPM level of $2.5 \mathrm{mg} / \mathrm{cig}$;

Cigarette B is a commercial cigarette with a TPM level of $2.6 \mathrm{mg} / \mathrm{cig}$;

Cigarette $\mathrm{C}$ is an experimental cigarette with a TPM level of $1.1 \mathrm{mg} / \mathrm{cig}$;

Cigarette D is a commercial cigarette with a TPM level of $30.4 \mathrm{mg} / \mathrm{cig}$;

Cigarette $\mathrm{E}$ is a commercial cigarette with a TPM level of $29.0 \mathrm{mg} / \mathrm{cig}$;

Cigarette $\mathrm{F}$ is a commercial cigarette with a TPM level of $28.5 \mathrm{mg} / \mathrm{cig}$;

Cigarette $\mathrm{G}$ is a commercial cigarette with a TPM level of $1.2 \mathrm{mg} / \mathrm{cig}$.

\section{Smoking conditions}

Cigarettes were smoked on a single port Filamatic smoking machine, as described at the $45^{\text {th }}$ Tobacco Chemists' Research Conference (3), using Federal Trade Commission (FTC) standard smoking conditions. Each cigarette type was smoked in triplicate. The whole mainstream smoke from each cigarette was collected at $0{ }^{\circ} \mathrm{C}$ in a train of two Midvale bulbs (Figure 1), each containing $20 \mathrm{~mL}$ of DiW. The term, whole mainstream smoke or whole smoke, is used to refer to the complete mainstream smoke, gas phase and particulate matter, all of which is directed into the trapping medium without any intervening trapping device. This apparatus has been successfully used for several years in trapping whole smoke in water. At the end of the smoking, the first Midvale bulb is sealed with a Teflon stopper, and the collection train is let stand in ice-water for $5.0 \mathrm{~min}$ (stopwatch). Then the first bulb's contents are poured into a $125 \mathrm{~mL}$ boiling flask, the contents of the second trap poured into the first bulb, and then transferred at once into the boiling flask. The flask is stoppered and the $40 \mathrm{~mL}$ combined sample is hand-shaken briefly. About 4 $\mathrm{mL}$ of the combined sample is passed through a pre-washed (10 mL methanol, then $50 \mathrm{~mL}$ DiW) C18 Sep-pak® cartridge (Waters Part No. WAT051910), discarded, then about $6 \mathrm{~mL}$ of the sample is pushed through the Sep-pak cartridge, and ultra-filtered through a UniPrep ${ }^{\circledR} 0.2 \mu \mathrm{m}$ PVDF 66 syringeless filter (Whatman Part No.UN113EAQU). The sample is then ready for IC injection.

\section{Ion chromatographic anion analyses}

All anion analyses were performed on the Dionex IonPac ${ }^{\circledR}$ AS11 column installed with a guard column in a Dionex 4500i ion chromatograph equipped with conductivity detection. The following mobile phase and double gradient program have been used successfully for a great range of anion analyses after the initial isocratic elution. The front end equilibration and isocratic step ensures retention time consistency for all analytes. The IC sequence is given in Table 1.

The 4500i ion chromatograph was equipped with a conductivity detector. The limit of detection for nitrite and nitrate ions was $5 \mathrm{ng} / \mathrm{cig}$ for $20 \mu \mathrm{L}$ injection volumes.

Detection was by conductivity (CD) and by UV, with a Perkin Elmer LC-235 Diode Array Detector (DAD) connected in series after the conductivity detector. The essentially neutral effluent from the AS11 column, followed by the suppression system, did not adversely affect the baseline for either the CD or the DAD. Typically, $20 \mu \mathrm{L}$ sample injections were made from whole smoke collected in DiW, with $200 \mu \mathrm{L}$ DiW washings between each injection. Injections were made within one hour of sample preparation. When this protocol could not be observed, the smoke collection sample was immediately frozen.

Figure 2 displays an ionogram of a standard anion mixture obtained on the AS11 column. This separation pattern was used as a reference throughout this work. An important feature of this column is its ability to generate baseline separation of inorganic and organic anions from the same 


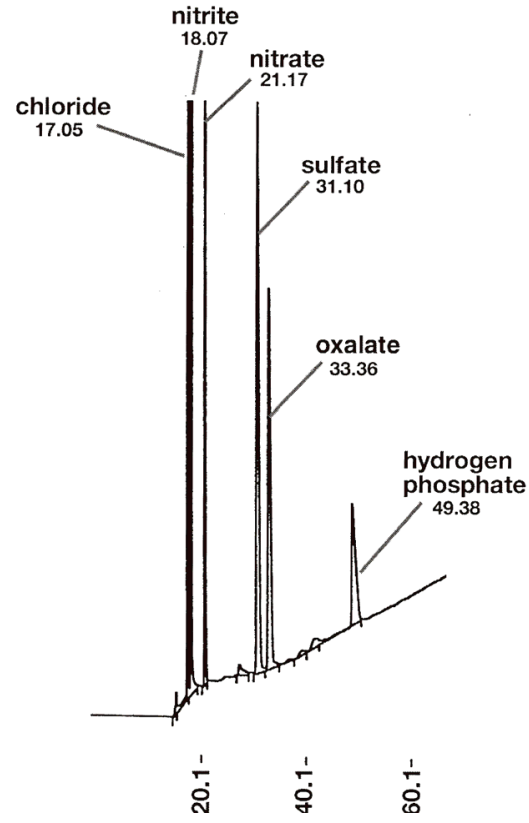

Figure 2. lonogram of a standard anion mixture

Table 2. Anions tested by IC in tobacco and smoke studies in order of increasing retention time

\begin{tabular}{lll}
\hline \multicolumn{2}{l}{ Anions tested by IC } & \\
\hline Fluoride & Benzoate & Fumarate \\
Acetate & Phenoxide & Maleate \\
Formate & Bisulfite & Sulfate \\
Propionate & Hydrogen phosphite & Tartrate \\
Glycolate & Carbonate & Mesaconate \\
Valerate & Sulfite & Oxalate \\
Chloride & Sulfide & Oxalacetate \\
Nitrite & Citraconate & Hydrogen phosphate \\
Bromide & Malate & Citrate \\
Cyanide & Succinate & lodide \\
Nitrate & Malonate & Thiocyanate \\
\hline
\end{tabular}

mixture. Over 40 anions have been tested by IC in our laboratories in order to acquire a sense of anion retention time and relative intensity. Table 2 lists 33 of these species in order of increasing IC retention times.

As a rule, an IC separation progresses first according to charge, and then by mass. The few exceptions can be explained by polarizability factors. For example, singly charged iodide is retained longer than even triply charged species, such as citrate.

\section{Ultraviolet spectrophotometry}

All UV spectra were obtained on DiW or DiW-diluted samples on a Kontron Uvicord ultraviolet-visible spectrophotometer. Scans were between $250-400 \mathrm{~nm}$ at absorption ranges up to $0.05-0.125$ absorbance units full scale (aufs).

\section{RESULTS AND DISCUSSION}

Since the initial experiments involving our work were focused on species different from peroxynitrite, the process whereby we concluded the identity of the ionic species found adjacent to the nitrite peak in aqueous IC profiles from collected cigarette smoke requires clarification. Several means were brought to bear on the identification and corroboration of the structure assignment to the unexpected smoke component bearing peroxynitrite properties. An unexpected aspect of this species was its relative stability in the whole smoke collected in water. Now, one might argue that the peroxynitrite anion could conceivably be formed during the collection of the whole smoke in water. Perhaps it might be possible to test this possibility, which, however, is somewhat beyond the scope of this paper. There are a number of important factors, which militate against the likelihood of artifactual formation of this species in the aqueous collection medium. Since water is already present at percent levels in smoke, the peroxynitrite ion is likely to have been formed in such a water-influenced environment prior to collection in the same. Further, the evidence accumulated by many researchers points strongly to the need for superoxide and nitric oxide to interact to form peroxynitrite $(14,15,18,24,28)$. Consequently, this event takes place in smoke, thus consuming a portion of the very reactive precursors, and therefore leading to a relatively longer lived species, namely, the title compound. A recent paper by VENKATARAMAN (29) illustrates the interaction of the dominant $N$-containing gas produced during smoking, nitric oxide, with the collecting medium, water, as shown below:

$$
4 \cdot \mathrm{NO}+\mathrm{O}_{2}+2 \mathrm{H}_{2} \mathrm{O} \Rightarrow 4 \mathrm{HONO}
$$

The IC evidence consistently shows that the bulk of the ensuing product trapped in water is nitrous acid ionized as nitrite. Further oxidation of the nitrous acid in situ will also produce nitric acid or nitrate.

The ionogram for a low 'tar' commercial cigarette B with a TPM level of $2.6 \mathrm{mg} / \mathrm{cig}$ (Figure 3 ) is compared with the ionogram for cigarette A with a TPM, $2.5 \mathrm{mg} / \mathrm{cig}$ (Figure 4). One should note the "clean" or empty region between the nitrite and the nitrate peaks in Figure 3. By contrast, Figure 4 displays the unexpected species I incompletely resolved from the nitrite peak.

This was the first instance of such behavior in a smoke IC anion profile. The unexpected, but strikingly different, pattern appeared between the well-separated nitrite (r.t., $18.26 \mathrm{~min}$ ) and nitrate (r.t., $22.88 \mathrm{~min}$ ) peaks. In cigarette whole smoke collections, the nitrite peak is typically dominant. The unknown I adjacent to the nitrite peak actually exhibited twice the area of the nitrite peak. In a separate experiment, the same phenomenon was displayed by another experimental cigarette $\mathrm{C}$, with a TPM, $1.1 \mathrm{mg} / \mathrm{cig}$. Later on, several different cigarette examples of varying, but higher 'tar' levels than in the cigarette in Figure 3, were shown to exhibit the same peak as well as a number of other unknown species in the same region. 


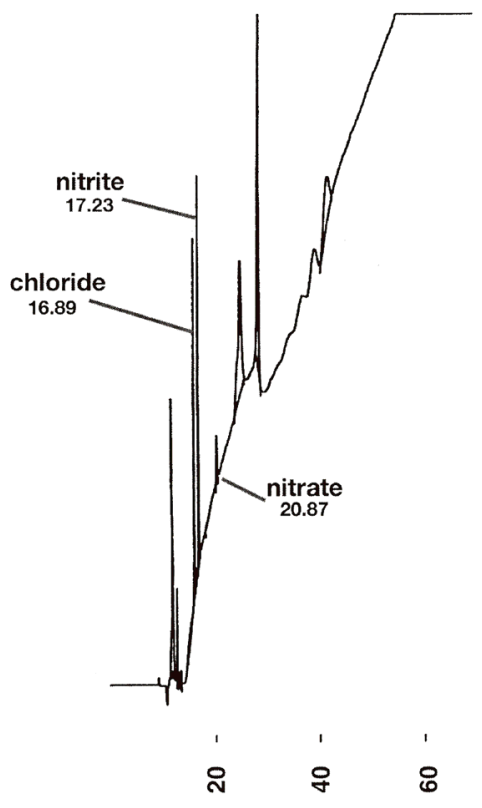

Figure 3. lonogram for low 'tar' commercial cigarette B whole smoke extract in deionized water

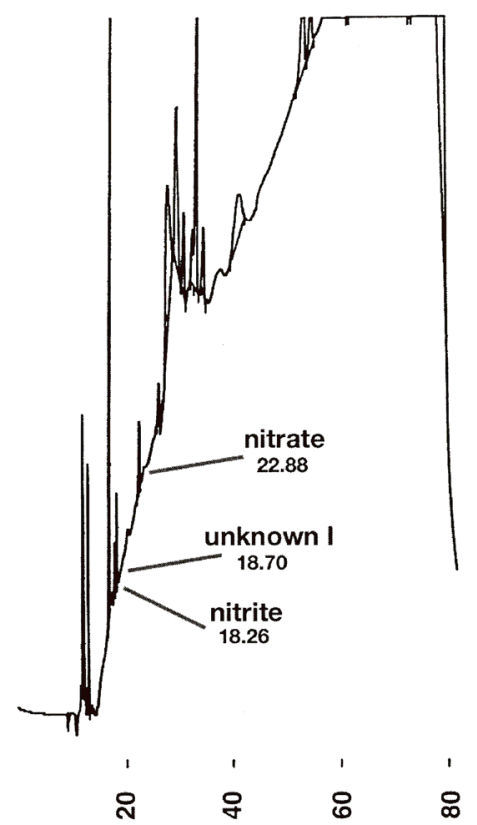

Figure 4. lonogram for experimental cigarette A whole smoke extract in deionized water

Therefore, a key factor leading to the identification of anion I required the optimization of the IC separation conditions to clearly separate the unknown peak I from nitrite. By using a milder gradient, as shown in the program below, an 8 minute-wide window was generated between nitrite (r.t., $19.33 \mathrm{~min}$ ) and nitrate (r.t., $26.69 \mathrm{~min}$ ) (Table 3).

This change afforded baseline separation of the unknown peak I, but it also revealed a number of additional peaks (Figure 5). These species will be referred as ion I (r.t., $20.04 \mathrm{~min}$ ), the major new ion previously overlapping with the nitrite peak, II (r.t., $18.62 \mathrm{~min}$ ), III (r.t., $20.89 \mathrm{~min}$ ), and
Table 3. Program for anion separation on the lonPac ${ }^{\circledR}$ AS 11 column

\begin{tabular}{l|c|c|c|c}
\hline $\begin{array}{l}\text { Time } \\
(\min )\end{array}$ & $\begin{array}{c}100 \mathrm{mM} \\
\mathrm{NaOH}\end{array}$ & $\mathrm{DiW}$ & $\begin{array}{c}10 \mathrm{mM} \\
\mathrm{NaOH}\end{array}$ & Action \\
\hline 0 & 0 & 90 & 10 & Equilibrate \\
8.9 & 0 & 90 & 10 & Equilibrate \\
9.0 & 0 & 90 & 10 & Inject \\
9.2 & 0 & 90 & 10 & Load reset \\
40.0 & 0 & 60 & 40 & Gradient 1 \\
40.1 & 0 & 60 & 40 & Peak resolve \\
75.0 & 20 & 80 & 0 & Gradient 2 \\
75.1 & 0 & 90 & 10 & Reset
\end{tabular}

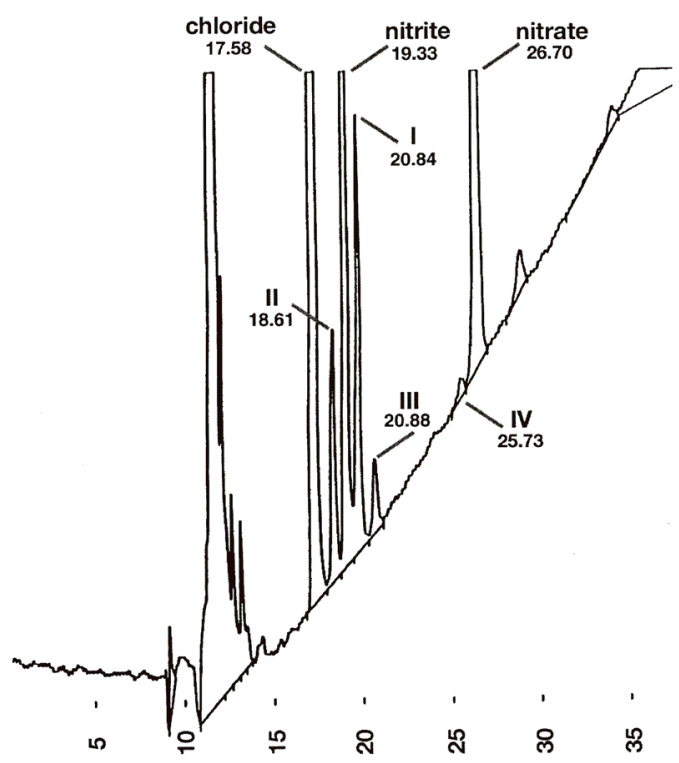

Figure 5. Resolution of nitrite and nitrate region in the cigarette A smoke extract ionogram

IV (r.t., $25.73 \mathrm{~min}$ ). Note that the retention times are not necessarily in numerical order with the peak assignments. As will be shown later, there is evidence that these species are interrelated.

Of all the ion species, considered because of their structure, which had been injected on this column, two were rejected as candidates early on. All of these possessed retention times close to that of peak $\mathbf{I}$ in the whole smoke extract.

a) Bromide was rejected, simply because it seldom shows up even in tobacco samples. Even if present in smoke, it would be at low ppb levels, almost undetectable here.

b) Cyanide $\left(\mathrm{CN}^{-}\right)$was considered, but independent smoke analyses for cyanide showed higher ppb levels for the commercial cigarette than for cigarette A. The cyanide ion conducts poorly, so that the levels of the unknown here would have to correspond to high 100's ppm cyanide. A Prussian Blue test for cyanide on the fresh smoke sample proved negative.

The region in question indicated $N$-containing ions. Therefore, the following were considered:

- Hydrogen hyponitrite: $\mathrm{HNNOO}^{-}$

- Peroxynitrite: ONOO

- Peroxynitrate $\mathrm{OONOO}^{-}$ 


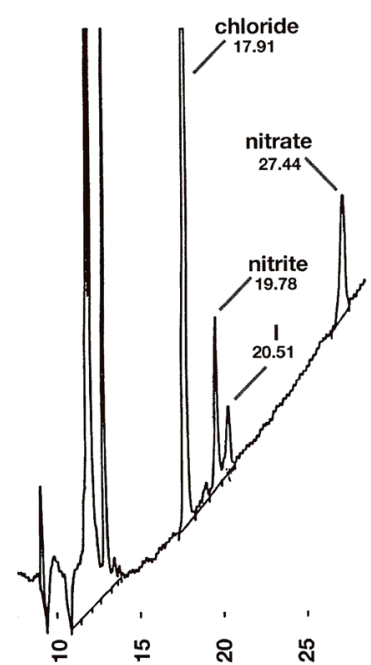

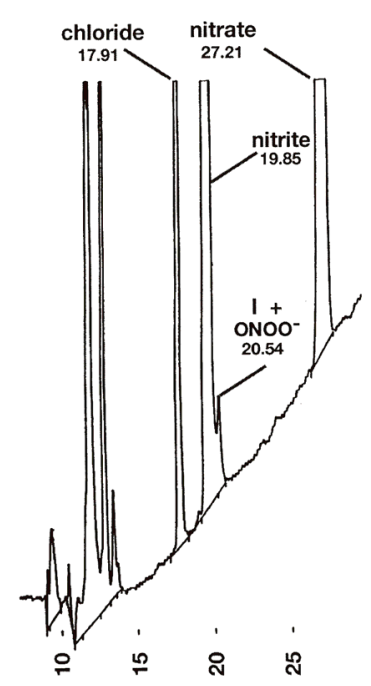

(b)
Figure 6. Ionogram for cigarette A whole smoke in deionized water (a) before and (b) after spiking with synthetic peroxynitrite

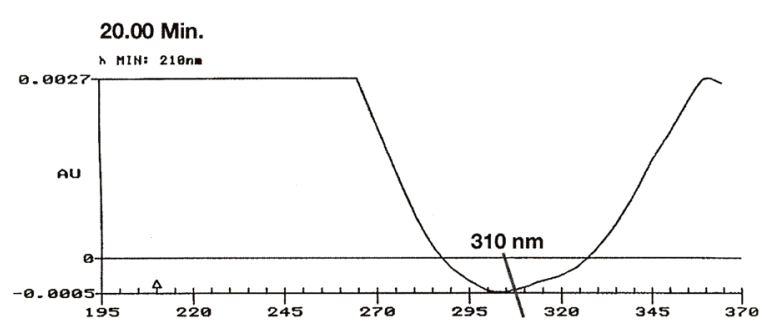

(a)

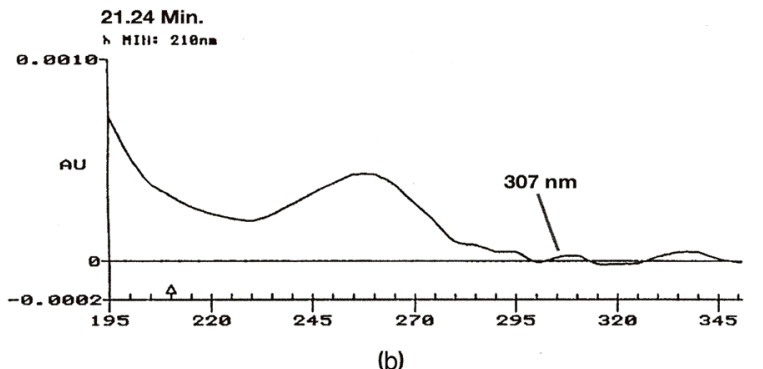

(b)

Figure 7. Comparative DAD UV spectra for (a) diluted synthetic peroxynitrite mixture and (b) peak I

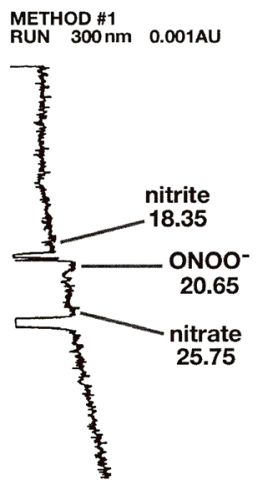

(a)

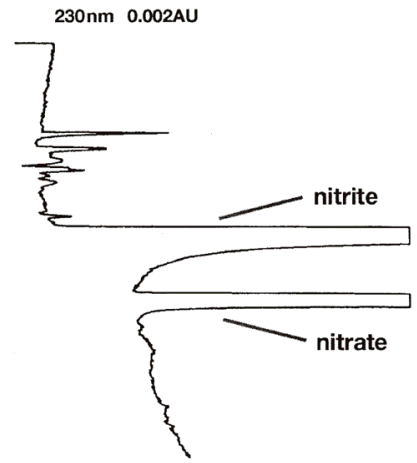

(b)
Figure 8. Ionograms with DAD SCANS at (a) $300 \mathrm{~nm}$ and (b) $230 \mathrm{~nm}$ for injected peroxynitrite mixture c) Hydrogen hyponitrite was a possibility. It can be made by reduction of aqueous sodium nitrite. This ion is stable, but the addition of acid decomposes it to nitrous oxide $\left(\mathrm{N}_{2} \mathrm{O}\right)$ and hydroxyl anion (28). It will be shown later on that these are not the products formed from the cigarette A smoke sample when treated with acid.

d) Consequently, peroxynitrite was the most logical candidate due to its structure and proximity to nitrite itself.

e) Peroxynitrate, which has been explored by PRYOR in cigarette smoke (18), could be expected to be interrelated with the peroxynitrite ion.

The following series of events in the formation of peroxynitrite has been documented by PRYOR's group and several other researchers through numerous studies of cigarette smoke $(18,30)$.

Formation of peroxynitrite ion in smoke

1) $\mathrm{O}_{2}+\mathrm{e}^{-} \rightarrow \mathrm{O}_{2}^{-\cdot} \rightarrow \mathrm{H}_{2} \mathrm{O}_{2} \rightarrow \mathrm{OH}^{\cdot}$

2) $\mathrm{NO} \rightarrow \mathrm{O}_{2}^{-\cdot} \rightarrow \mathrm{ONOO}^{-}$

3) $\mathrm{ONOO}^{-} \rightarrow \mathrm{ONOOH} \rightarrow \mathrm{NO}_{2}^{-}+\mathrm{OH}^{\circ}$

The available oxygen from the air generates the superoxide radical ion through the intermediacy of quinone/hydroquinone-like redox systems. Superoxide and the nitric oxide produced during smoking interact to produce peroxynitrite and further related species, including peroxynitrous acid, nitrogen dioxide radical and hydroxyl radical. When $18 \mu \mathrm{L}$ of whole smoke from cigarette A, collected in DiW, was spiked with $2 \mu \mathrm{L}$ of $1 / 64$ diluted synthetic peroxynitrite solution, peak I was clearly enhanced. Even though the synthesized peroxynitrite contained a considerable amount of excess nitrite and nitrate, the 20-21 minute region for peak I remained sharp after spiking. This experiment is illustrated in Figure 6.

The UV spectrum for the synthetic peroxynitrite preparation shows a maximum at $302 \mathrm{~nm}\left(\mathrm{e}=1670 \mathrm{M}^{-1} \mathrm{CM}^{-1}\right)$. Comparing $100 \mu \mathrm{L}$ injections of the diluted synthetic mixture of peroxynitrite with the collected whole smoke water extract in the peak I region (20-21 min), one finds a clear shoulder at $310 \mathrm{~nm}$ for the synthetic peroxynitrite DAD UV spectrum (Figure 7a). This preparation contains a large concentration of both nitrite and nitrate, which affect the UV pattern. The DAD UV spectrum for the $300 \mathrm{~nm}$ 20-21 min region peak shows a maximum in the same UV region, at $307 \mathrm{~nm}$ (Figure 7b).

The ionogram (Figure 8) for the synthetic peroxynitrite mixture (at $1 / 64$ of the original concentration) with DAD at 230 and $300 \mathrm{~nm}$ clearly shows the small but distinct peak for $\mathrm{ONOO}^{-}$at $20.65 \mathrm{~min}$. The modestly negative nitrite and nitrate peaks at the $300 \mathrm{~nm}$ DAD setting become overwhelming at the $230 \mathrm{~nm}$ setting. The ionogram for cigarette A whole smoke collected in water (Figure 9) unequivocally shows the positive peak at 21.2 min for peak I at $300 \mathrm{~nm}$ DAD setting and still present at $230 \mathrm{~nm}$ because the nitrite and nitrate concentrations are not overwhelming in this smoke sample as compared with the reference peroxynitrite preparation.

Dilute mineral acid, such as $0.05 N$ sulfuric acid, instantaneously destroys I found in whole smoke collected in water from cigarette A as evidenced by the total dis- 


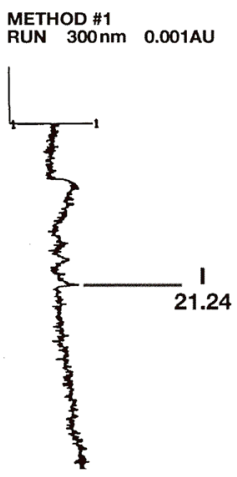

(a)

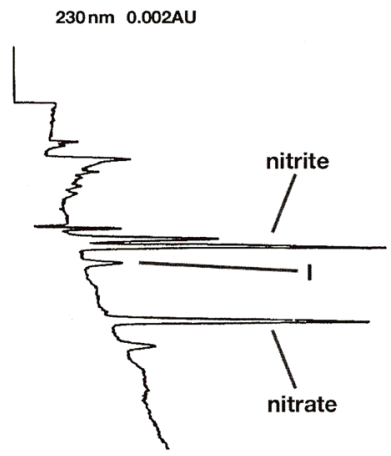

(b)
Figure 9. Ionograms with DAD scans at (a) $300 \mathrm{~nm}$ and (b) 230 $\mathrm{nm}$ for injected cigarette $A$ whole smoke collected in deionized water

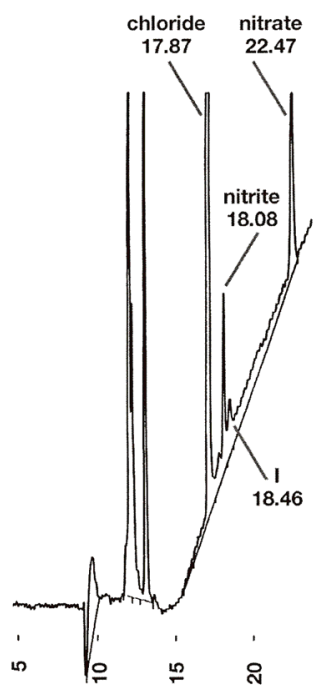

(a)

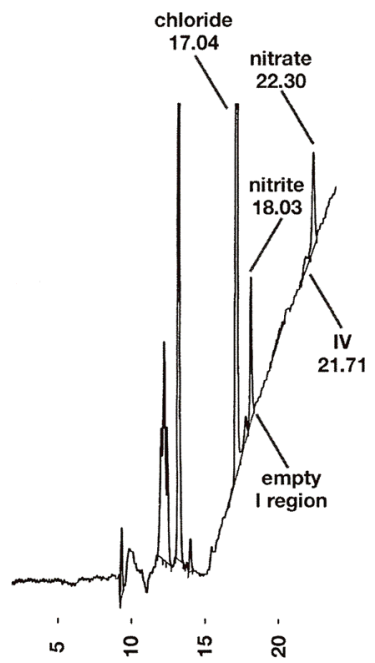

(b)
Figure 10. Cigarette A peak I behavior over weeks at room temperature $\left(25^{\circ} \mathrm{C}\right)$

appearance of the peak and a concomitant increase in the nitrate peak. Sulfuric acid, rather than hydrochloric, was chosen because of the relatively greater distance of the sulfate ion from the nitrite region as compared with chloride. The baseline rises steeply because of the presence of excess sulfate, but the region of interest remains clear. Figure 10 illustrates the disappearance of peak I after time at room temperature. This event occurs much earlier than over several weeks, but, at the mild $\mathrm{pH}$ of collection, which is essentially neutral, the peroxynitrite peak is remarkably

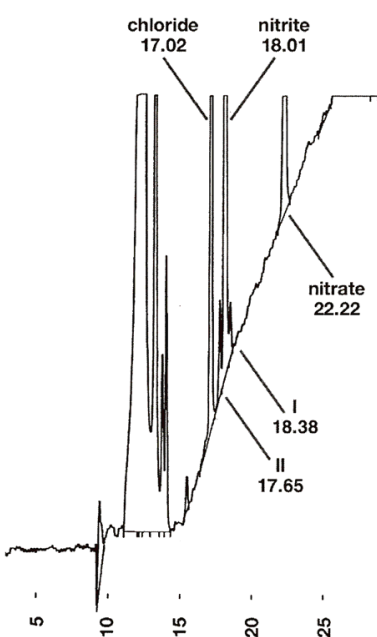

(a)

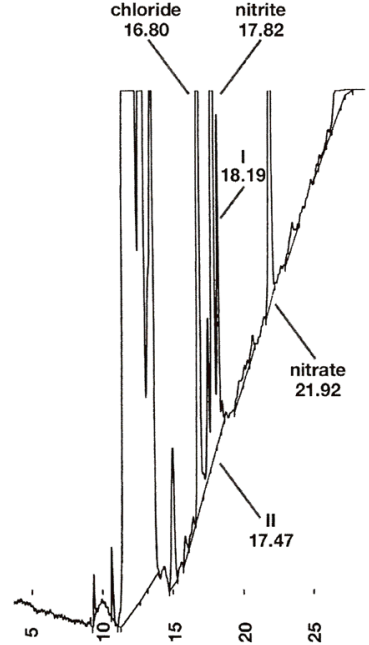

(b)
Figure 11. lonograms for cigarette B whole smoke collected in $10 \mathrm{mM}$ sodium hydroxide [(a) filter vs. (b) no filter]

long lived. This lifetime could be checked against that of the authentic synthetic, diluted peroxynitrite sample, which, however, was always accompanied by large amounts of nitrite and nitrate. It is interesting that peak IV, which appears immediately before nitrate, grows concomitantly with the loss of peak I. This breakdown product may be peroxynitrate, which could be expected to be somewhat more long-lived than its reduced precursor. It is significant to observe the remarkable increase in I and the many satellite peaks in the nitrite-nitrate region when the cigarette filter has been removed (Figure 11). Clearly, filtration is quite effective in trapping either this species or its precursor quinone/hydroquinone redox couple and nitric oxide even with full flavor cigarettes.

Some full flavor and low 'tar' cigarettes are compared in their whole smoke concentration for nitrite, nitrate and I (calculated as if it were nitrite in detector response). They are listed as cigarettes D, E, F, and G, and are described in the Experimental Section according to TPM level.

The results of these analyses are expressed in Table 4.

Since ion I does decompose with time at room temperature, the values given for this species are useful due to their trend indication, but are on the low side. It appears that the combined ion values follow 'tar' levels.

Concentrations were then determined for nitrite, nitrate and I for cigarette $\mathrm{D}$ with and without filtration. The results are listed in Table 5, with the inclusion of the combined nitrite, nitrate and ion I concentrations in $\mu \mathrm{g} / \mathrm{cig}$, which are essentially ppm levels.

There is a remarkable increase of 4.2 fold in the concentration of $\mathbf{I}$ when the cigarette filter has been removed,

Table 4. Whole smoke nitrogen anion distribution in commercial cigarettes

\begin{tabular}{|c|c|c|c|c|c|c|}
\hline Sample & $\mathrm{NO}_{2}^{-}(\mu \mathrm{g} / \mathrm{cig})$ & $\mathrm{NO}_{3}^{-}(\mu \mathrm{g} / \mathrm{cig})$ & Ion I ( $\mu \mathrm{g} / \mathrm{cig})$ & $\begin{array}{c}\text { Combined } \\
\mathrm{NO}_{2}^{-} \mathrm{NO}_{3}^{-} \text {ion I }(\mu \mathrm{g} / \text { cig })\end{array}$ & Puff count & $\begin{array}{c}\text { TPM } \\
\text { (mg/cig) }\end{array}$ \\
\hline Cigarette D & 145.5 & 39.2 & 3.1 & 187.8 & 8.5 & 30.4 \\
\hline Cigarette E & 107.4 & 30.1 & 3.3 & 140.8 & 8.8 & 29.0 \\
\hline Cigarette F & 89.5 & 30.4 & 2.4 & 122.3 & 9.8 & 28.5 \\
\hline Cigarette G & 24.4 & 6.4 & $<0.005$ & 30.8 & 8.5 & 1.2 \\
\hline
\end{tabular}


Table 5. Whole smoke nitrogen anion distribution in cigarette $D$ with and without filtration

\begin{tabular}{l|c|c|c|c|c|}
\hline Sample & $\mathrm{NO}_{2}^{-}(\mu \mathrm{g} / \mathrm{cig})$ & $\mathrm{NO}_{3}^{-}(\mu \mathrm{g} / \mathrm{cig})$ & Ion I $(\mu \mathrm{g} / \mathrm{cig})$ & $\begin{array}{c}\text { Combined } \\
\mathrm{NO}_{2}^{-} \mathrm{NO}_{3}^{-} \text {ion I }(\mu \mathrm{g} / \mathrm{cig})\end{array}$ & Puff count \\
\hline $\begin{array}{l}\text { Cigarette D } \\
\begin{array}{l}\text { Cigarette D (filter } \\
\text { removed) }\end{array}\end{array}$ & 145.5 & 39.2 & 3.1 & 187.8 & 8.5 \\
\hline
\end{tabular}

from an average of $3.1 \mu \mathrm{g} / \mathrm{cig}$ to $12.9 \mu \mathrm{g} / \mathrm{cig}$. It is particularly intriguing that ion I (peroxynitrite) or its precursors are removed so much more efficiently than nitrite or nitrate. Perhaps this observation could be applied to practical selective filtration approaches.

\section{CONCLUSIONS}

During routine IC analyses of an experimental cigarette whole smoke collected in water, a new ion was detected adjacent to nitrite. Evidence for the assignment to this new species as peroxynitrite was found in the relative instability of this species over time, correspondence of IC retention times with an authentic sample of the peroxynitrite ion synthesized from hydrogen peroxide and isoamyl nitrite, UV spectral data, and chemical behavior in the presence of dilute mineral acids. The levels of this species in the whole smoke of some commercial cigarettes ranged from $2.4-3.3 \mu \mathrm{g} / \mathrm{cig}$. It is significant that, when the filter is removed, a four-fold increase in peroxynitrite is observed. This is the first time that IC has been used to detect and separate such a species, and the first time that peroxynitrite ion has been identified in smoke.

The benefit to the scientific community of measuring such a potentially elusive species by a reliable analytical means such as IC and conductivity/UV absorption detection, should be considerable. This would be particularly true for studies involving the dynamic behavior of collected smoke. It is particularly interesting, and useful, to have determined that peroxynitrite is relatively long-lived in whole smoke collected in water. Future work will encompass further structural elucidation and additional comparative cigarette studies.

\section{ACKNOWLEDGMENTS}

The authors would like to thank Alan Burrows, John Chapman, Lawrence Gains, Darrell Joyce, Bob Lake, Marty Sudholt, and Rana Walker.

\section{REFERENCES}

1. Akehurst, B.C.: Tobacco; Longman Group, Ltd., London, U.K., 1968.

2. Stedman, R.L.: The chemical composition of tobacco and tobacco smoke; Chem. Rev. 68 (1968) 153-207.

3. Perini, F.R.: Procedure for water-soluble anion determination in tobacco and related solid matrices; 45th Tobacco Chemists' Research Conference, Program Booklet and Abstracts, Vol. 45, Paper No. 39, 1991, p. 34.
4. Cooney, R.V. and P.D. Ross: $N$-Nitrosation and $N$ nitration of morpholine by nitrogen dioxide in aqueous solution: effects of vanillin and related phenols; J. Agr. Food Chem. 35 (1987) 789-793.

5. Cooney, R.V., P.D. Ross, G.L. Bartolini, and J. Ramseyer: $N$-Nitrosoamine and $N$-nitroamine formation: factors influencing the aqueous reactions of nitrogen dioxide with morpholine; Environ. Sci. Technol. 21 (1987) 77-83.

6. Pourcelot, S., H. Faure, and J. Hee: Comparison of urinary excretion of DNA base adducts between smokers and non-smokers; Bull ARN (1999) 5-15.

7. Iho, S., Y. Tanaka, R. Takauji, C. Kobayashi, I. Muramatsu, H. Iwasaki, K. Nakamura, Y. Sasaki, and T. Takahashi: Nicotine induces human neutrophils to produce IL-8 through the generation of peroxynitrite and subsequent activation of NF-.kappa.B; J. Leukocyte Biol. 74 (2003) 942-951.

8. Yamaguchi, Y., S. Kagota, J. Haginaka, and M. Kunitomo: Participation of peroxynitrite in oxidative modification of LDL by aqueous extracts of cigarette smoke; FEBS Lett. 512 (2002) 218-222.

9. Takajo, Y, H. Ikeda, N. Haramaki, T. Murohara, and T. Imaizumi: Augmented oxidative stress of platelets in chronic smokers. Mechanisms of impaired plateletderived nitric oxide bioactivity and augmented platelet aggregability; J. Amer. Coll. Cardiol. 38 (2001) 1320-1327.

10. Kato, H., T. Miyazaki, M. Yoshikawa, M. Nakajima, Y. Fukai, K. Tajima, N. Masuda, S. Tsutsumi, K. Tsukada, T. Nakajima, and H. Kuwano: Nitrotyrosine in esophageal squamous cell carcinoma and relevance to p53 expression; Cancer Lett. 153 (2000) 121-127.

11. Lin, J.-K., K.-J. Chen, G.-Y. Liu, Y.-R. Chu, and S.-Y. Lin-Shiau: Nitration and hydroxylation of aromatic amino acids and guanine by the air pollutant peroxyacetyl nitrate; Chem.-Biol. Interact. 127 (2000) 219-236.

12. Yamaguchi, Y., S. Kagota, J. Haginaka, and M. Kunitomo: Peroxynitrite-generating species: good candidate oxidants in aqueous extracts of cigarette smoke; Japan J. Pharmacol. 82 (2000) 78-81.

13. Chang, Y-C., K.-W. Tai, M.-Y. Chou, and T.-H. Tseng: Synergistic effects of peroxynitrite on arecolineinduced cytotoxicity in human buccal mucosal fibroblasts; Toxicol. Lett. 118 (2000) 61-68.

14. Müller, T. and S. Gebel: The cellular stress response induced by aqueous extracts of cigarette smoke is critically dependent on the intracellular glutathione concentration; Carcinogenesis 19 (1998) 797-801.

15. Müller, T., H.-J. Haussmann, and G. Schepers: Evidence for peroxynitrite as an oxidative stressinducing compound; Carcinogenesis 18 (1997) 295-301. 
16. Yoshie, Y. and H. Ohshima: Synergistic induction of DNA strand breakage by cigarette tar and nitric oxide; Carcinogenesis 18 (1997) 1359-1363.

17. Deliconstantinos, G., V. Villiotou, and J.C. Stavrides: Scavenging effects of hemoglobin and related heme containing compounds on nitric oxide, reactive oxidants and carcinogenic volatile nitroso compounds of cigarette smoke. A new method for protection against the dangerous cigarette constituents; Anticancer Res.14 (1994) 2717-2726.

18. Pryor, W.A. and K. Stone: Oxidants in cigarette smoke: radicals, hydrogen peroxide, peroxynitrate, and peroxynitrite; Ann. N. Y. Acad. Sci. 686 (1993) 12-28.

19. Pouli, A.E., D.G. Hatzinikolaou, Ch. Piperi, A. Stavridou, M.C. Psallidopoulos, and J.C. Stavrides: The cytotoxic effect of volatile organic compounds of the gas phase of cigarette smoke on lung epithelial cells; Free Rad. Biol. Med. 34 (2003) 345-355.

20. Runge, M.S., B. Vanhouten, and S.W. Ballinger: Mitochondrial DNA damage as a predictor of coronary atherosclerotic heart disease; US Patent No. 20030404945 (2003, February 27).

21. Morot-Gaudry-Talarmain, Y., P. Rockel, T. Moureaux, I. Quillere, M.T. Leydecker, W.M. Kaiser, and J.F. Morot-Gaudry: Nitrite accumulation and nitric oxide emission in relation to cellular signaling in nitrite reductase antisense tobacco; Planta 215 (2002) 708-715.

22. Runge, M.S., S.W. Ballinger, and B. Vanhouten: Using mitochondrial DNA damage as a predictor of coronary atherosclerotic heart disease; US Patent No. 6322974 (2001, November 27).

23. Clark, D., J. Durner, D.A. Navarre, and D.F. Klessig: Nitric oxide inhibition of tobacco catalase and ascorbate peroxidase; Molec. Plant-Microbe Interact. 13 (2000) 1380-1384.

24. Deliconstantinos, G. and V. Villiotou: Gas phase oxidants of cigarette smoke increase nitric oxide synthase and xanthine oxidase activities of rabbit brain synaptosomes; Neurochem. Res. 25 (2000) 769-774.
25. Moreno, J.J.: Studies on cigarette smoke: I. Inactivation of $\alpha$-1-PI. II. Oxidation of methionine by peroxonitrite. III. Release of iron from ferritin by smoke solutions; Diss. Abstr. Int. B 52 (1992) 4711-12.

26. Perini, F.R., E.A. Robinson, and L.H. Gains: Evidence for peroxynitrite and cognates in whole smoke; 55 th Tobacco Science Research Conference, Program Booklet and Abstracts, Vol. 55, Paper No. 90, 2001, p. 72.

27. Uppu, R.M. and W.A. Pryor: Synthesis of peroxynitrite in a two-phase system using isoamyl nitrite and hydrogen peroxide; Anal. Biochem. 236 (1996) 242-249.

28. Squadrito, G.L. and W.A. Pryor: The formation of peroxynitrite in vivo from nitric oxide and superoxide; Chemical-Biol. Interact. 96(1995)203-206.

29. Venkataraman, S., S.M. Martin, F.Q. Schafer, and G.R. Buettner: Detailed methods for the quantification of nitric oxide in aqueous solutions using either an oxygen monitor or EPR; Free Radical Biol. Med. 29 (2000) 580.

30. Zhu, S., M. Manuel, S. Tanaka, N. Choe, and E. Kagan: Contribution of reactive oxygen and nitrogen species to particulate-induced lung injury; Environ. Health Perspect. Suppl. 106 (1998) 1157-1163.

Corresponding author:

Florian R. Perini

A.W. Spears Research Center

Lorillard Tobacco Company

P.O. Box 21688

Greensboro, N.C. 27420-1688

USA

E-mail:fperini@lortobco.com 